\title{
Effect of Covid-19 in Jordan: Conceptual Analysis of Different Economic Sectors
}

\author{
Saddam Ali Shatnawi \\ Faculty of Economics and Muamalat, Universiti Sains Islam Malaysia \\ 71800 Nilai, Negeri Sembilan, Malaysia \\ E-mail: saddamshatnawiusim@yahoo.com \\ Bilal Khalaf Sakarneh \\ Dean of Buisness College, ISRA University, Amman, Jordan \\ E-mail: bilal_sakarneh@iu.edu.jo
}

Received: March 24, 2021 Accepted: April 21, $2021 \quad$ Published: May 24, 2021

doi:10.5296/ber.v11i2.18672ＵＵＵ： Uttps://doi.org/10.5296/ber.v11i2.18672

\begin{abstract}
Jordan, similar to other nations around the globe, has been severely affected by the COVID-19 pandemic cut across Jordanian service, banking, insurance, and industrial sectors. The spread of the virus and attempts to control it have generated both social and economic turbulence, turmoil, disorder, uncertainty, and uneasiness in the country. The government of Jordan acted promptly in March 2020 by ordering a national lockdown to mitigate the impact of COVID-19 on these economic sectors. The COVID-19 has had both direct and indirect negative effects on these sectors, which are projected to vary from the short to the long term. It is possible to measure the short-term effects as seen in this conceptual work. Some of the short-term effects anticipated include economic recession, high unemployment rate, high inflation, etc. In conclusion, these sectors will continue to encounter challenges because of the ongoing economic slowdown in Jordan due to lockdown and other social measures put in place by the government. Currently, there is yet to be a tentative and complete statistical prediction of the negative economic effects and cost of COVID-19 in Jordan, particularly on its sectors of the economy.
\end{abstract}

Keywords: Banking, COVID-19, Industrial, Insurance, Jordan, Service 


\section{Introduction}

COVID-19 pandemic is no longer new. The spread of the virus has affected huge numbers of peoples in different states, countries, and the world at large. Jordan has acted well in lessening the health effect of the COVID-19 pandemic. Following the outbreak in the country, the government of Jordan declared measures and support to address the direct huge impact and cost of cushion up several sectors/industries and to protect susceptible of its people (AlQutob et al., 2020a). However, national lockdowns, then international economic slowdown, business/ market interferences, and the suspension of global traveling have a substantial effect on all work of Jordanian sectors, including service, banking, insurance, and industrial sectors (AlQutob et al., 2020b). The unexpected economic shock caused by COVID-19 has aggravated current structural flaws in the economy and undetermined social challenges and place a burden on Jordan's fragile economy (Al-Tammemi, 2020).

Major issues facing Jordan include the protracted drop in economic activities in sectors such as banking, industrial, and insurance due to national lockdowns, which further worsen high unemployment rates (Nicola et al., 2020). As a result of the lockdown, the Jordanian services sector, the leading sector of the country's economy, severely hit. With additional economic restrictions, there is a likelihood that the Jordanian government can take greater strict measures if the COVID-19 infection persistent in the country (Khatatbeh, 2020). After the pandemic, likely, the economy of Jordan in these four sectors (service, banking, insurance, and industrial) could be further affected.

Since June 2020, Jordan has considerably relieved restrictions on economic activity and the country has progressively reported low cases of COVID-19 (Al Sawalqa, 2020). However, Jordan has not been able to predict the negative economic effects of COVID-19 cost on all its sectors of the economy, which are compelled to dawdle for the coming years (Oxford Analytica, 2020). The author further indicated that rapid economic salvage in the medium-term mostly depends on the progress of the COVID-19 whether transformations are set into effect.

Moreover, the effect of COVID-19 on the banking sector can be noticed on the net profit after tax reported ascribable to stakeholders for the first to the second quarter of 2020 (during the peak of COVID-19) for the listed companies on the Amman Stock Exchange (ASE; Mondo, 2020). According to ASE, the profit has declined from JD 268.5 million to JD 88.6 million from the first to the second quarter. The profit before tax for these companies shrunk from JD 386.5 million to JD 162.4 million during this period of COVID-19. Concerning the service sector, the profits after the tax cut down by $277.3 \%$, while the industrial sector declined by $59.0 \%$, and lastly the financial sector with $47.0 \%$ shrinkage. These issues are further elaborated under the subsequent headings, consistent with the purpose of this study to examine the effect of COVID-19 in Jordan service, banking, insurance, and industrial sectors.

\section{Effect of COVID-19 on Jordanian Service Sector}

The service sector plays a significant role in global economic development. The sector is made up of over 70\% of the gross domestic product (GDP) in 2019 based on World 
Development Indicators (Dalevska et al., 2019). The service sector has to turn out to be the sole biggest sector in several economies in the world including Jordan, comprising three-fourths of GDP in developed nations, and a slighter but growing share in developing nations. Employment in the service sector is highly vital as its productivity. Jordan's economy is overshadowed by the services sector concerning value-added and employment. According to the Hashemite Kingdom of Jordan Department of Statistics, the employment rate falls steadily from July 2017 to July 2020. With COVID-19, the employment rate falls from $27.6 \%$ to $26.3 \%$.

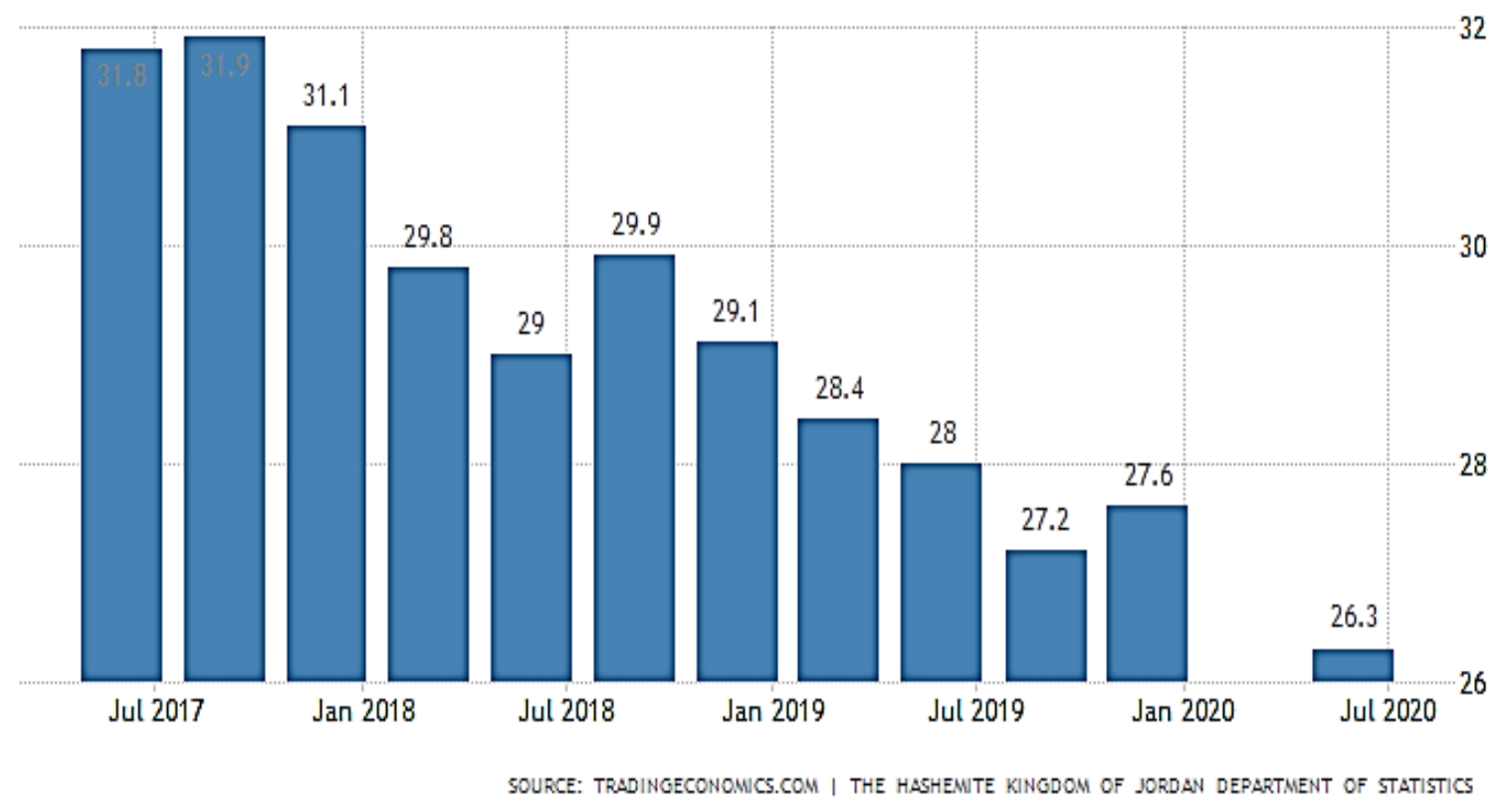

Figure 1. Jordan Employment Rate from July 2017 to July 2020 Data

The speedy eruption of the COVID-19 pandemic casts a first-time effect on the services industry globally, including Jordan (Heinonen \& Strandvik, 2020). According to Baker et al. (2020), its unprecedented characteristics might likely that COVID-19 will change the manner the services are planned and provided. Consistent with the service sector in Jordan, the effect of COVID-19 is deep and is yet to define on full scale but the impact currently very visible on the value-added, employment rate, and service-delivering rate (Dodds \& Hess, 2020). This is particularly in the views of employees, organizations, industries, and governments.

The development of services trade and its extensive accessibility in Jordan can be critical and challenging during the ongoing COVID-19, which signifies a vital cause of an economic downturn (Nicola et al., 2020). Certainly, one of the crucial economic natures of numerous services is their enabling function, the advantages of an effective services sector go beyond the service sector itself, and are experienced via their effects on other economic events. Al Sawalqa (2020) indicated that the economic recovery in Jordan through the coming quarters may be very low or negative as external demand remains very fragile, and downside risk remains and originating from the COVID-19 with a possible negative effect. Based on this 
available information, the following hypothesis can be proposed:

H1: COVID-19 pandemic has a negative effect on the development of the service sector in Jordan.

\section{Effect of COVID-19 on Jordanian Banking Sector}

The banking sector is one of the strong and most developed sectors in Jordan, and it remains robust in the face of substantial external volatility and maintaining its function as a driver of economic growth before COVID-19. The sector has been a key source of strength, having the Central Bank of Jordan (CBJ) providing a pro-growth financial position (Demirguc-Kuntet al., 2020). The banking sector represents $4 \%$ of GDP between January and May of 2020 (World Bank, 2020), making it one of the prime economic sectors in the country.

Even with current regional volatility, COVID-19 pandemic, low oil prices, and the slowdown of GDP growth in the country, the banking sector remains robust, steady, and appealing to investors (Demirguc-Kunt et al., 2020). Even though banks remain generally profitable industry, following the COVID-19 pandemic signify the sector might be set to suffer consolidation (Alheet\& Hamdan, 2020; Hobeika et al., 2020). The fiscal consolidation of the banks is estimated at 4\% of GDP during 2020 (IMF, 2020). This is because the Jordanian economy has persistently encountered substantial challenges. Economic stability and external cushions are conserved, but fiscal susceptibilities remain. Physical transformations and continuous fiscal consolidation support are crucial in boosting growth in Jordan, the action decrease unemployment and debt burden. However, the COVID-19 pandemic poses major threats to such transformation in Jordanian banks, to reduce the effect the new financial strategy is put in place.

The new financial strategy is the Arab Monetary Fund that comprised countries such as Algeria, Bahrain, Comoros, Djibouti, Egypt, Iraq, Jordan, Kuwait, Lebanon, Libya, Mauritania, Morocco, Oman, Palestine, Qatar, Saudi Arabia, Somalia, Sudan, Syria, Tunisia, United Arab Emirates, and Yemen. The disbursed financing approval to Jordan is based on a pre-existing arrangement that amounts to $\$ 38$ million and the policies or initiatives are based on central banks, which issued general guidelines for the COVID-19 deal (Stubbs et al., 2020). Directors supported the new financial strategy, which centers on fiscal consolidation and growth-stimulating reforms, nevertheless, the continuous spread of the COVID-19 pandemic might put the financial strategy at peril (IMF, 2020 Wójcik \& Ioannou, 2020). The general implications of COVID-19 for banks and capital markets are presented in Table 1 . These implications are important in helping the banks and capital markets in Jordan to further understands how to contain the ongoing COVID-19 and its anticipated second wave. 
Table 1. Overall implications of COVID-19 for banks and capital markets in Jordan

\begin{tabular}{|c|c|c|}
\hline Implications & Present and Potential Issues & Important Questions \\
\hline $\begin{array}{l}\text { COVID-19 } \\
\text { preparedness }\end{array}$ & $\begin{array}{l}\text { - COVID-19 upset the operations of several } \\
\text { banks and capital markets companies. } \\
\text { - Although banks and capital markets have } \\
\text { already taken actions, but the companies may } \\
\text { need to do more as the circumstances develop. }\end{array}$ & $\begin{array}{l}\text { - What is the appropriate way to } \\
\text { measure the precise banking } \\
\text { response? } \\
\text { - How is the COVID-19 internal } \\
\text { and external task force } \\
\text { emboldened? }\end{array}$ \\
\hline $\begin{array}{l}\text { Monitoring } \\
\text { evaluation }\end{array}$ & $\begin{array}{l}\text { - The evolving events about COVID-19 call for } \\
\text { banks to be active/adaptable. }\end{array}$ & $\begin{array}{l}\text { - Is the situation strategy being } \\
\text { performed positively? } \\
\text { - Are strategies, policies, and } \\
\text { measures adaptive/flexible, and } \\
\text { are they according to national and } \\
\text { local guidelines? } \\
\text { - Is there any reliable governance } \\
\text { mechanism in place if the } \\
\text { COVID-19 situation exacerbates? }\end{array}$ \\
\hline $\begin{array}{l}\text { Quality of operational } \\
\text { efficiency and } \\
\text { employee welfare }\end{array}$ & $\begin{array}{l}\text { - The continuous spread and cases of COVID-19 } \\
\text { might further affect bank tasks and operations as } \\
\text { governments, educational institutions, public } \\
\text { agencies, and offices adjust their practices and } \\
\text { strategies. }\end{array}$ & $\begin{array}{l}\text { - How can banks ensure the } \\
\text { quality of work efficiency remains } \\
\text { high as COVID-19 progress? } \\
\text { - How can banks sustain } \\
\text { employee commitment, welfare, } \\
\text { and motivation as the virus halt } \\
\text { works? }\end{array}$ \\
\hline $\begin{array}{l}\text { Infrastructural } \\
\text { capability }\end{array}$ & $\begin{array}{l}\text { - In order to facilitate flexible remote operations, } \\
\text { banks and capital markets ought to have } \\
\text { appropriate infrastructures }\end{array}$ & $\begin{array}{l}\text { - Are essential technical } \\
\text { infrastructures in place to support } \\
\text { alternative operational activities, } \\
\text { and how safe are they? } \\
\text { - Which existing devices can } \\
\text { support distant bank teamwork? }\end{array}$ \\
\hline Communications & $\begin{array}{l}\text { - COVID-19 hinder regular and face to face } \\
\text { communication with stakeholders, this may } \\
\text { continue to progress in the expected second } \\
\text { wave }\end{array}$ & $\begin{array}{l}\text { - How rapidly can banks' } \\
\text { communications be effectively } \\
\text { used to reach all stakeholders in } \\
\text { all platforms and regions? }\end{array}$ \\
\hline
\end{tabular}

Source of information: IMF (2020); Hobeika et al. (2020); Nicola et al. (2020); Stubbs et al. (2020)

Hobeika et al. (2020) reported that the continuous spread of the virus in 2020 will have a strong negative effect on banks and capital markets operations across the Jordanian economy. However, Li et al. (2020) showed that the more the cases of COVID-19 progress, the banks as lenders of a first resort would encounter many challenges with their customers as a result of the adjustment to various bank policies and measures to contain the COVID-19 pandemic. The author further added that the situation might likely go beyond the current virus. As a result of these facts explained above, the following hypothesis can be proposed:

H2: COVID-19 pandemic has a negative effect on the operations and policies of the banking sector in Jordan.

\section{Effect of COVID-19 on Jordanian Insurance Sector}

The Jordanian insurance sector is smaller than the banking and capital market sector. The insurance sector supports financial service development for higher profits, penetrating 
strength, and gross written premium (Al-Ajlouni \& Al Rabayah, 2020). The effect of the COVID-19 pandemic on insurers in Jordan includes a rapid increase in health, travel, and business disruption claims, the burden on trades due to cut down in business activity, and less utilization of direct channels due to social distancing measure (Al-Ajlouni \& Al Rabayah, 2020; Khersiat \& Alkabbji, 2020). The collective economic deceleration originating from the COVID-19 effect is pushing the interest rates even lesser and amplifying credit risk exposing businesses to potential default. This presents the likelihood of the regulators demanding unexpected solvency assessments to ensure insurers can survive the direct and knock-on effects of the pandemic (French, 2020). Altogether, this formidable list of issues symbolizes a harsh test of flexibility for a sector already overloaded by perpetually low interest rates and lingering growth in developed markets.

The COVID-19 has both short-term and long-term effects on the Jordanian insurance sector. In terms of short-term perspective, the sector is mostly prepared for key loss events including COVID-19, where the financial effects will take time to be clear and insurer specific (Wójcik \& Ioannou, 2020). Insurers have taken a couple of actions against the spreading of the COVID-19 pandemic in many ways including claims made by employees, customers, important partners, etc. covering cost-sharing for COVID-19 treatments or preventive service (Garrett \& Gangopadhyaya, 2020; Omoush et al., 2020). These claims amounted to millions to billions of Jordanian dinar for account holders. Each has its distinctive challenges, not only for the insurance sector but also for the world economy. Although Jordan has experienced a relative degree of success in controlling the spread of the COVID-19 infection, this has come at a severe economic cost. The country is predicted to experience a severe recession in 2020 that will increase unemployment rates and put a significant burden on domestic income and spending (Acs \& Karpman, 2020; Al Sawalqa, 2020; Oxford Analytica, 2020). Consequently, a lower demand across the life and non-life insurance sector is expected. However, health insurance is expected to witness an increase in demand from households that can afford insurance cover (AlQutob et al., 2020a; Hobeika et al., 2020).

Conversely, in term of the long-term perspective effect, the sector is expected to face financial effects of COVID-19 on insurers to be precise to the situations of each business including classes and mix of business they guarantee, their valuing and reserving, policy phrasings, and protection coverage (Acs \& Karpman, 2020; Baumann, 2020). Table 2 presents the long-term effect of COVID-19 on the insurance sector in Jordan. The potential long-term issues facing the insurance companies are display followed by crucial questions for executives and boards to consider. These issues or questions constitute the major challenges prompted by the COVID-19 pandemic. 
Table 2. Long-term effect of COVID-19 on insurance sector in Jordan

\begin{tabular}{|c|c|}
\hline Potential long-term effect on insurance sector & Important Questions \\
\hline $\begin{array}{l}\text { - Declining equity markets and interest rates might } \\
\text { place a burden on (re)insurers' balance sheets, life } \\
\text { product productivity and investment administration } \\
\text { fees associated with savings products. } \\
\text { - There is potential time-lag for insurance claims to be } \\
\text { informed to insurers, evaluated, and compensated. } \\
\text { Insurers have begun the procedure of assessing their } \\
\text { claims investments consistent with the present } \\
\text { situations and it is anticipated that this continuous as } \\
\text { facts develop. } \\
\text { - Insurers with developed risk portfolios will be the } \\
\text { most protected against losses from COVID-19. } \\
\text { However, those with a great concentration of classes } \\
\text { of trade/company most uncovered to COVID-19 might } \\
\text { be negatively affected. }\end{array}$ & $\begin{array}{l}\text { - What protections are in place to enable the } \\
\text { well-being of customers and distribution partners in } \\
\text { the agent/broker markets? } \\
\text { - How do insurance companies facilitate and maintain } \\
\text { efficient alternate work measures for workers? } \\
\text { - How do insurance companies ensure continuous } \\
\text { enhancement in virtual environment efficiency? } \\
\text { - How do insurance companies' best boost working } \\
\text { burden implication concerning improved levels of } \\
\text { consumer inquiry and the improved level of support? } \\
\text { - Does the company's existing internet security } \\
\text { provide adequate protection in considerably improved } \\
\text { capacity and new ways of operation and swapping } \\
\text { information? }\end{array}$ \\
\hline
\end{tabular}

Source of information: Acs \& Karpman (2020); Baumann (2020); Omoush et al. (2020)

Studies have indicated that the COVID-19 pandemic has a significant effect on the insurance industry throughout the globe and the developing countries will face a higher decrease in equity markets and interest rates (Babuna et al., 2020; Omoush et al., 2020). It has also been reported that the COVID-19 pandemic will negatively affect employment, income, and unemployment insurance across the world (Acs \& Karpman, 2020). Moreover, Garrett \& Gangopadhyaya (2020) that eminent recession as a result of COVID-19 could affect health insurance coverage. Based on these facts discussed earlier, as well as the nature and current situations of the COVID-19 about the insurance sector in Jordan, the following hypothesis can be proposed:

H3: COVID-19 pandemic has a negative effect on insurance claims, coverage, and operations in Jordan.

\section{Effect of COVID-19 on Jordanian Industrial Sector}

The COVID-19 pandemic is accompanied by a multitude of challenges to the Jordanian industrial sector, particularly those that rely on employees whose works cannot be remotely operated. Around $75 \%$ of manufacturers/companies in Jordan anticipate that the virus will have an economic effect on their businesses (Bsisu, 2020). This is considerably greater than the 52\% of cross-industry firms that are worried regarding a similar effect (Rutgers, 2020). Many manufacturing/ engineering firms in Jordan anticipate COVID-19 to affect (62\%) their operations (Alabdullah et al., 2020). These likelihoods have become a reality in the sector. Certain key industrial firms have closed facilities and are considering downsizings to aid reduce the spread of the coronavirus, and economic concern. The industrial sector is a great contributor to Jordanian GDP because it contributed about 22\% in 2019 and employing over 239,000 Jordanians (Al-Froukh, 2019). The industrial sector is set to be hard-knock during ongoing COVID-19, basically because of two motives: One, several industrial works are on-site and cannot be remotely conducted. Two, the slowdown of economic activity has 
decreased the demand for industrial products across Jordan.

Protecting customer's and employees' health is the priority for all businesses and governments (Hollingsworth, 2020). The industrial and construction facilities closures between March to July 2020 might continue to be crucial as a formidable measure to prevent COVID-19 spread (especially for the expected second wave that is already striking) for companies in hard-hit areas in Jordan, in case of an extended period of the virus (AlQutob et al., 2020b). For businesses susceptible to a pandemic is now a crucial time to explore a proactive utilization of modernized and mechanized technologies, such as industrial two-way robotics, independent object movement, and industrial internet of things, to cut employee density through their operations (Bsisu, 2020; Saidan et al., 2020; Werman, 2020).

Several factors can improve the performance of companies (Shatnawi et al, 2019a,b; Shatnawi et al, 2020). On another hand, the failure of financial performance is witnessed around the world particularly in the Islamic Financial Institutions of Islamic countries in addition to weak CG structures (Eldaia et al., 2020a;b). Short-term impact includes uncertainty enveloping the extent of these situations of the virus overshadows any understandings of how recovery is unfolding for the industry. Several long-suffering businesses in manufacturing can be qualified for the government of Jordan stimulus support. However, there is a likelihood that the pandemic will result in liquidation for some companies due to falling demand and revenues, accompanied by debt liabilities, which take their mounting pressure (Nicola et al., 2020). However, in terms of longer-term potential effects, companies in Jordan will face some important challenges in the production and delivery of industrial products across the countries, including an all-inclusive outlook of the potential threat, increase in discerning of products manufacture, among others (Table 3).

Table 3. Long-term effect of COVID-19 on the industrial sector in Jordan

\begin{tabular}{|l|l|}
\hline Potential long-term effect on the industrial sector & Important Questions \\
\hline - Adjourn important investments. & $\begin{array}{l}\text { - How effective to protect all employees particularly } \\
\text { - Take an additional all-inclusive outlook of potential } \\
\text { those in the frontline of operation? }\end{array}$ \\
threat. & $\begin{array}{l}\text { - How can a company measure and alleviate risk } \\
\text { through the complete supply chain? }\end{array}$ \\
- Companies ought to be more discerning regarding & $\begin{array}{l}\text { - How can a company use communication approaches } \\
\text { the manufacture of the product. }\end{array}$ \\
$\begin{array}{l}\text { - Engage in higher vertical integration and active } \\
\text { and public relations to cheer up the shareholders, } \\
\text { that. }\end{array}$ & $\begin{array}{l}\text { - What is the new norm in terms of market situations } \\
\text { response, and position in the market? }\end{array}$ \\
\hline
\end{tabular}

Source of information: Bsisu (2020); Saidan et al. (2020); Werman (2020)

Considering that the effects of COVID-19 are experienced around the globe, several industrial products companies in Jordan are challenging with production obstacles. This is because of supply chain interference and labor force dislodgment, which negatively affect general productions, engineers, and construction in Jordan (del Rio-Chanona et al., 2020). As the negative effect of COVID-19 is experienced, several companies mostly anticipate interruption to continuous supply chain, cost appreciation, and prolongs in product conveyance (Bsisu, 2020). The sector will probably be hindered by the general decline in 


\section{Macrothink}

demand (Saidan et al., 2020). Based on these obtainable facts, the following hypothesis can be proposed:

H4: COVID-19 pandemic has a negative effect on the industrial sector in Jordan.

Generally, the COVID-19 will negatively affect all aspects of the service, banking, insurance, and industrial sectors in Jordan. The present study is proposing a research framework (Figure 2) in which COVID-19 has a direct effect and relationship with service, banking, insurance, and industrial sectors in Jordan. Based on the review of available literature and various issues identified, the following propositions are hence proposed;

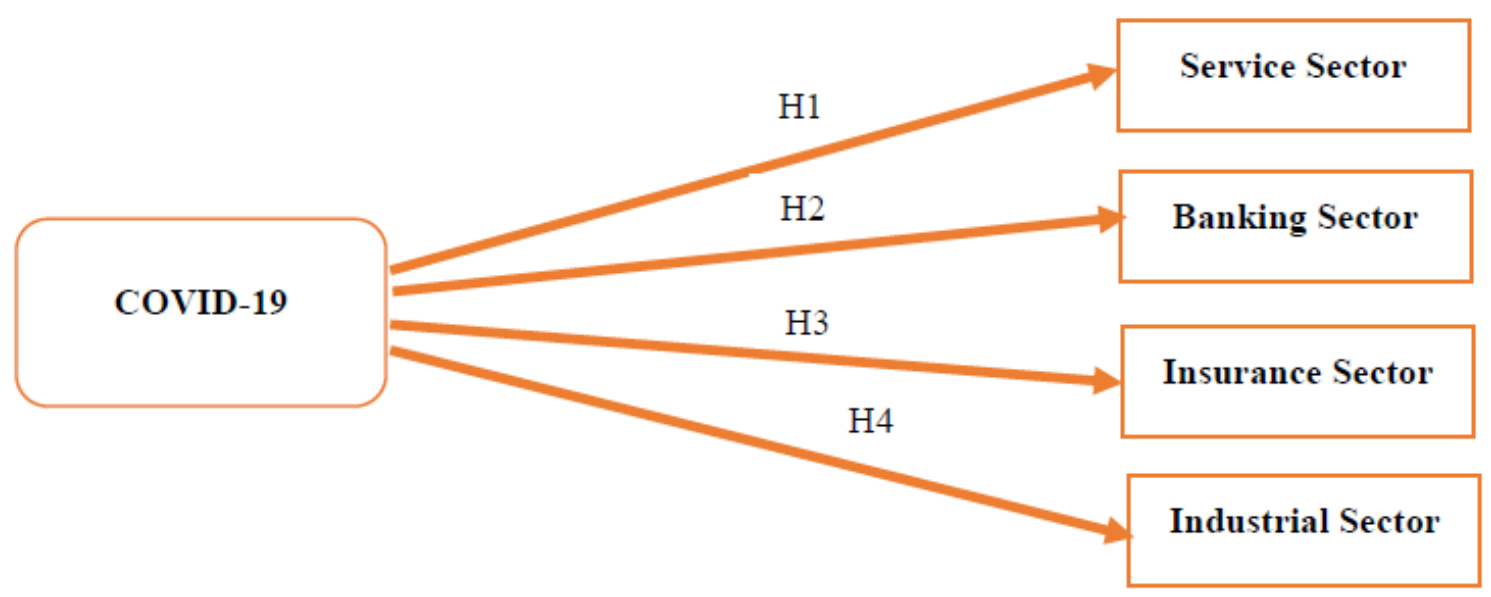

Figure 2. Conceptual Framework

\section{Conclusion}

The COVID-19 is well much with us; its effect is felt across all work of life and sectors. The negative effect of the virus on several sectors, including service, banking, insurance, and industrial sectors in Jordan are now reported. Jordanian financial services and labor markets remain a strong economic engine and growth driver, with significant potential imminent economic recession knocking at the country door. These sectors will continue to encounter challenges because of the ongoing economic slowdown in Jordan due to lockdown and other social measures put in place by the government. Currently, there is yet to be a tentative and complete statistical prediction of the negative economic effects and cost of COVID-19 in Jordan, particularly on its sectors of the economy. The COVID-19 effects on Jordanian economic sectors are proposed to linger in the coming years. . In China, due to improvement in the health care system life expectancy increased remarkably between 1969 and 1982 especially in rural areas (Guo, 2017). More than $50 \%$ of the Jordanian population is youths that are within working age, with the bulk of them employed in service, banking, insurance, and industrial sectors. This workforce has been heavily affected by the lockdown caused by the pandemic.

The Jordanian economic sectors were identified to face triple crisis cut-across service, 
banking, insurance, and industrial sectors, these are health, social, and economic. These gave rise to the basic question; how will the Jordanian government mitigate/moderate the effects of COVID-19 on its economic sectors to protect the economy and Jordanian health? The answer to this question will entail the nature of cushion-up arrangements in place and a kind of support the sectors will be anticipating from the government. The confound mix of uncertain nature of the COVID-19 effect, particularly the expected second wave, is mounting internal pressure on demands of these sectors, which will likely force Jordan to review its policy placement. The COVID-19 effects on Jordanian economic sectors are proposed to linger in the coming years. There are several directions for future research long-term effects while measuring long-term effects is challenging considering numerous issues facing the Jordanian service, banking, insurance, and industrial sectors. Jordanian financial services and labor markets remain a strong economic engine and growth driver, with significant potential imminent economic recession knocking at the country door.

\section{References}

Acs, G., \& Karpman, M. (2020). Employment, Income, and Unemployment Insurance during the COVID-19 Pandemic. Urban Institute. https://doi.org/10.20955/es.2020.33

Al Sawalqa, F. A. (2020). Risk Disclosure Patterns among Jordanian Companies: An Exploratory Study during the COVID-19 Pandemic. Accounting and Finance Research, 9, 3. https://doi.org/10.5430/afr.v9n3p69

Al-Ajlouni, R., \& Al Rabayah, A. (2020). Will Jordan be closer to UHC after the COVID-19 pandemic?. Journal of Global Health, 10(2). https://doi.org/10.7189/jogh.10.020360

Alheet, A. F., \& Hamdan, Y. (2020). Evaluating innovation-driven economic growth: a case of Jordan. Entrepreneurship and Sustainability Issues, 7(3), 1790-1802.

https://doi.org/10.9770/jesi.2020.7.3(23)

AlQutob, R., Ajlouni, M., AbuFarraj, M., \& Moonesar, I. (2020a). Jordan's Public and Surveillance Health Policies: During and After COVID-19. Jordan Journal of Pharmaceutical Sciences, 13(3), 1-12. https://doi.org/10.2196/preprints.19672

AlQutob, R., Al Nsour, M., Tarawneh, M. R., Ajlouni, M., Khader, Y., Aqel, I., ... Obeidat, N. (2020c). COVID-19 crisis in Jordan: Response, scenarios, strategies, and recommendations. JMIR public health and surveillance, 6(3), e19332. https://doi.org/10.2196/19332

AlQutob, R., Moonesar, I. A., Tarawneh, M. R., Al Nsour, M., \& Khader, Y. (2020b). Public Health Strategies for the Gradual Lifting of the Public Sector Lockdown in Jordan and the United Arab Emirates During the COVID-19 Crisis. JMIR Public Health and Surveillance, 6(3), e20478. https://doi.org/10.2196/20478

Al-Tammemi, A. A. B. (2020). The battle against COVID-19 in Jordan: an early overview of the Jordanian experience. Frontiers in Public Health, 8, 188.

https://doi.org/10.3389/fpubh.2020.00188

Babuna, P., Yang, X., Gyilbag, A., Awudi, D. A., Ngmenbelle, D., \& Bian, D. (2020). The 
Impact of COVID-19 on the Insurance Industry. International journal of environmental research and public health, 17(16), 5766. https://doi.org/10.3390/ijerph17165766

Baker, S. R., Bloom, N., Davis, S. J., Kost, K., Sammon, M., \& Viratyosin, T. (2020). The unprecedented stock market reaction to COVID-19. The Review of Asset Pricing Studies. https://doi.org/10.3386/w26945

Baumann, N. (2020). Understanding the sector impact of COVID-19 Insurance. Deloitte Touche Tohmatsu Limite, pp. 1-2.

Bsisu, K. A. D. (2020). The Impact of COVID-19 Pandemic on Jordanian Civil Engineers and Construction Industry. International Journal of Engineering Research and Technology, 13, 828-830. https://doi.org/10.37624/IJERT/13.5.2020.828-830

Dalevska, N., Khobta, V., Kwilinski, A., \& Kravchenko, S. (2019). A model for estimating social and economic indicators of sustainable development. Entrepreneurship and Sustainability Issues, 6(4), 1839-1860. https://doi.org/10.9770/jesi.2019.6.4(21)

del Rio-Chanona, R. M., Mealy, P., Pichler, A., Lafond, F., \& Farmer, D. (2020). Supply and demand shocks in the COVID-19 pandemic: An industry and occupation perspective. arXiv preprint arXiv:2004.06759. https://doi.org/10.1093/oxrep/graa033

Demirguc-Kunt, A., Pedraza, A., \& Ruiz-Ortega, C. (2020). Banking Sector Performance During the COVID-19 Crisis. https://doi.org/10.1596/1813-9450-9363

Dodds, S., \& Hess, A. C. (2020). Adapting research methodology during COVID-19: lessons for transformative service research. Journal of Service Management, 1757-5818.

https://doi.org/10.1108/JOSM-05-2020-0153

Eldaia, M., Hanefah, M. B. M., Marzuki, A. B., \& Shatnawi, S. (2020a). Takaful in Malaysia: Emergence, Growth, and Prospects. In Handbook of Research on Theory and Practice of Global Islamic Finance, IGI Global. pp. 681-702.

https://doi.org/10.4018/978-1-7998-0218-1.ch035

Eldaia, M., Hanefah, M.B.M., Marzuki, A.B., Shatnawi, S. (2020b), "Moderating Role of Shariah Committee Quality on the Relationship between Audit Committee and Malaysian Takaful Performance: A Litera-ture Review. International Journal of Islamic Economics, 2(1), 409-421. https://doi.org/10.32332/ijie.v2i01.2031

French, C. C. (2020). Covid-19 Business Interruption Insurance Losses: The Cases for and Against Coverage. Conn. Ins. LJ, 27, 1.

Garrett, A. B., \& Gangopadhyaya, A. (2020). How the COVID-19 Recession Could Affect Health Insurance Coverage. https://doi.org/10.2139/ssrn.3598558

Guo, Z. (2017). Health Insurance and the Demand for Medical Care: a Case Study from China. Asian Journal of Economics and Empirical Research, 4(1), 8-13.

https://doi.org/10.20448/journal.501.2017.41.8.13

Heinonen, K., \& Strandvik, T. (2020). Reframing service innovation: COVID-19 as a catalyst 
for imposed service innovation. Journal of Service Management, 32(1), 1757-5818. https://doi.org/10.1108/JOSM-05-2020-0161

Hobeika, G., Alaoui, R. H., Ramsdale, R. (2020). Coronavirus Poses Downside Risks to Jordanian Banks. Media Relations: Louisa Williams, London.

IMF. (2020). Article Iv Consultation And Request For An Extended Arrangement Under The Extended Fund Facility_Press Releases; Staff Report; And Statement By The Alternate Executive Director For Jordan. IMF Country Report No. 20/101.

https://doi.org/10.5089/9781513540306.002

Khatatbeh, M. (2020). Efficacy of nationwide curfew to encounter spread of COVID-19: a case from Jordan. Frontiers in Public Health, 8, 394.

https://doi.org/10.3389/fpubh.2020.00394

Khersiat, O. M., \& Alkabbji, R. F. (2020). Impact of the Application of IFRS 9 Standards on the Profits and Losses of Insurance Companies Listed on the Amman Stock Exchange. Academy of Strategic Management Journal, 19(1), 1-7.

Li, L., Strahan, P. E., \& Zhang, S. (2020). Banks as lenders of first resort: Evidence from the COVID-19 crisis. The Review of Corporate Finance Studies, 9(3), 472-500.

https://doi.org/10.1093/rcfs/cfaa009

Mondo, V. (2020). Amman Stock Exchange: The Financial Results Of The Companies Listed For The First Quarters \& First Half Of 2020. [Online] Available:

https://m.mondovisione.com/news/amman-stock-exchange-the-financial-results-of-the-compa nies-listed-for-the-firs-1/

Nicola, M., Alsafi, Z., Sohrabi, C., Kerwan, A., Al-Jabir, A., Iosifidis, C., ... Agha, R. (2020). The socio-economic implications of the coronavirus pandemic (COVID-19): A review. International journal of surgery (London, England), 78, 185.

https://doi.org/10.1016/j.ijsu.2020.04.018

Omoush, M., Moflih, M., \& Almetrami, R. (2020). Evaluating the Five Kaizen Success Measurements through Employees Work Improvement and its Effects on Overall Work and Quality of Services: Empirical Study of Insurance Companies in Jordan. International Review of Management and Marketing, 10(4), 43-52. https://doi.org/10.32479/irmm.9994

Oxford, A. (2020). COVID-19 will further set back Jordan's reform efforts. Emerald Expert Briefings, (oxan-DB).

Rutgers, V. (2020). COVID-19's impact on industrial products \& construction firms. Deloitte Touche Tohmatsu Limited (Deloitte Global), pp. 1-2.

Saidan, M. N., Shbool, M. A., Arabeyyat, O. S., Al-Shihabi, S. T., Al Abdallat, Y., Barghash, M. A., \& Saidan, H. (2020). Estimation of the probable outbreak size of novel coronavirus (COVID-19) in social gathering events and industrial activities. International Journal of Infectious Diseases, 98, 321-327. https://doi.org/10.1016/j.ijid.2020.06.105 


\section{Macrothink}

Business and Economic Research ISSN 2162-4860 2021, Vol. 11, No. 2

Shatnawi, S., Hanefah, M., \&Eldaia, M. (2019a). Moderating Effect of Enterprise Risk Management on the Relationship Between Board Structures and Corporate Performance. International Journal of Entrepreneurship and Management Practices, 2(6), 01-15. https://doi.org/10.35631/IJEMP.26001

Shatnawi, S., Hanefah, M., Adaa, A., \& Eldaia, M. (2019b). The Moderating Effect of Enterprise Risk Management on the Relationship between Audit Committee Characteristics and Corporate Performance: A Conceptual Case of Jordan. International Journal of Academic Research Business and Social Sciences, 9(5), 177-194.

https://doi.org/10.6007/IJARBSS/v9-i5/5849

Shatnawi, S., Hanefah, M., Anwar, N., \& Eldaia, M. (2020). The Factors Influencing the Enterprise Risk Management Practices and Firm Performance in Jordan and Malaysia: A Comparative Review. International Journal of Recent Technology and Engineering (IJRTE), 5(8), 687-702. https://doi.org/10.35940/ijrte.D8114.018520

Stubbs, T., Kring, W., Laskaridis, C., Kentikelenis, A., \& Gallagher, K. (2020). Whatever it takes? The global financial safety net, Covid-19, and developing countries. World Development, 137, 105171. https://doi.org/10.1016/j.worlddev.2020.105171

Werman, A. (2020). Jordan's rising economic challenges in the time of COVID-19. Middle East Institute, 1763 N St. NW, Washington D.C.

Wójcik, D., \& Ioannou, S. (2020). COVID-19 and Finance: Market Developments So Far and Potential Impacts on the Financial Sector and Centres. Tijdschrift voor economische en sociale geografie, 111(3), 387-400. https://doi.org/10.1111/tesg.12434

World Bank. (2020). The World Bank In Jordan. [Online] Available: https://www.worldbank.org/en/country/jordan/overview

\section{Copyright Disclaimer}

Copyright for this article is retained by the author(s), with first publication rights granted to the journal.

This is an open-access article distributed under the terms and conditions of the Creative Commons Attribution license (http://creativecommons.org/licenses/by/4.0/). 